\title{
KOORDINASI PUSKESMAS DENGAN KECAMATAN DALAM MENINGKATKAN KESEHATAN LINGKUNGAN DI KECAMATAN PAGADEN
}

\author{
Oleh : \\ Luki Natika \\ Fakultas Ilmu Administrasi Universitas Subang \\ luckynatika@gmail.com
}

\begin{abstract}
ABSTRAK
Penelitian ini mengkaji dan menganalisis mengenai Koordinasi Puskesmas Dengan Kecamatan dalam Meningkatkan Kesehatan Lingkungan di Kecamatan Pagaden. Pendekatan penelitian yang digunakan untuk mengkaji mengenai penelitian ini adalah pendekatan kualitatif yaitu prosedur penelitian yang menghasilkan data deskriptif berupa kata-kata tertulis atau lisan dari orang-orang dan perilaku yang dapat diamati. Pendekatan ini diarahkan pada latar dan individu tersebut secara holistik (utuh). Metode analisis dalam penelitian ini meliputi tiga yaitu reduksi, tampilan dan penarikan kesimpulan. Reduksi yaitu data yang dikumpulkan dipilih, disederhanakan, difokuskan, diabstraksikan dan ditransformasikan, tampilan yaitu data berupa teks naratif, matriks, kutipan, grafik ataupun bagan, tahapan selanjutnya adalah penarikan kesimpulan.

Hasil penelitian ini dapat disimpulkan bahwa 1) Pada koordinasi dalam penanganan kesehatan lingkungan sudah ada kesatuan tindakan, hal ini terbukti dengan adanya kerjasama antara Puskesmas Pagaden dan Kantor Kecamatan Pagaden dalam sosialisasi program kesehatan lingkungan kepada masyarakat, karena program kesehatan lingkungan tidak akan berjalan dengan baik bila tidak melibatkan unsur birokrasi di tingkat paling bawah. 2) Pelaksanaan program kesehatan lingkungan yang dilaksanakan oleh Puskemas Pagaden berjalan sesuai dengan rencana, yaitu pihak puskesmas dapat berkomunikasi dengan pihak kecamatan yang dapat dilihat dengan dukungan yang diberikan oleh pihak birokrasi berupa keterlibatan unsur birokrasi dan masyarakat dalam kegiatan-kegiatan yang dilaksanakan Puskesmas. 3) Pembagian kerja antara Puskesmas dan Kecamatan dalam pelaksanaan program kesehatan lingkungan secara spesifik kewenangan puskesmas dan kecamatan hanya berkoordinasi apabila ada kejadian seperti demam berdarah dan lain-lain baru jalur birokrasi dibuka dengan pengerahan aparat yang ada di daerah pelaksananya pihak kecamatan hanya sebatas membuat kebijakan seperti pembuatan Surat Keputusan dan Surat Perintah dan secara teknis ada pihak puskesmas, 4) Kesadaran dan kesediaan anggota dalam menjalankan tugas dapat mendukung koordinasi yang baik antara instansi terkait. Kesadaraan akan tugas yang diberikan kepada Puskesma Pagaden dan Kantor Kecamatan Pagaden serta kesediaan untuk menjalankan tugas hal yang sangat dituntut untuk pencapaian tujuan. Tanpa adanya kesadaran dan kesediaan setiap anggota pelaksanaan program kesehatan lingkungan
\end{abstract}

Kata Kunci : Koordinasi, Meningkatkan Kesehatan Lingkungan 


\begin{abstract}
This study examines and analyzes the health center with the District Coordination to Improve Environmental Health in the District Pagaden. The research approach used to assess the results of these studies are qualitative approach, the research procedures that produce descriptive data in the form of words written or spoken of people and behaviors that can be observed. This approach is directed at the individual's background and holistic (whole). The method of analysis in this study included three of reduction, display and conclusion. Namely the reduction of the collected data been simplified, focused, abstracted and transformed, to see that the data in the form of narrative text, matrix, quotes, graphs or charts, the next stage is the conclusion.
\end{abstract}

The results of this study concluded that 1) In coordination in the health care environment is already no unity of action, it is proved by the cooperation between PHC Pagaden and the District Office Pagaden in the socialization of environmental health programs to the community, because the environmental health program will not run properly when not involved in the bureaucracy at the lowest level. 2) Implementation of environmental health programs implemented by Puskemas Pagaden goes according to plan, the clinic is able to communicate with the district that can be seen with the support provided by the bureaucracy in the form of bureaucratic elements and community involvement in activities implemented PHC. 3) The division of labor between the health centers and sub-district in the implementation of environmental health programs specifically authorized health centers and districts only coordinate if there are events such as dengue fever and other new bureaucracy opened with the deployment of forces in the region implementing the district only a policy such as Decreemaking and Warrant and technically there is the clinic, 4) Awareness and willingness of members to perform tasks to support better coordination among relevant agencies. Awareness will be the task given to health center and district offices Pagaden Pagaden and a willingness to perform tasks very thing required for the achievement of objectives. Without the awareness and willingness of each member of the implementation of environmental health programs

Keywords: Coordination, Environmental Health Improving

\section{PENDAHULUAN}

Pembangunan yang sedang dilaksanakan dewasa ini adalah dalam rangka pembangunan manusia Indonesia seutuhnya. Oleh karena itu, pembangunan tersebut dilaksanakan untuk menciptakan kesejahteraan dan kemakmuran bagi seluruh rakyat Indonesia dalam suasana keseimbangan dan keselarasan pemenuhan kebutuhan, baik kebutuhan yang bersifat lahiriah maupun batiniah. Dengan demikian, arah pembangunan jangka panjang bukan hanya kenaikan pendapatan nasional yang menjadi tujuan pembangunan, akan tetapi pembangunan Nasional dilaksanakan dalam rangka pembangunan manusia Indonesia seutuhnya. Tujuan pembangunan seperti ini memuat ciri-ciri keselarasan kemajuan lahiriah dan kepuasan batin, keselarasan hubungan manusia dengan Tuhan, antara manusia dengan sesamanya, antara manusia dengan lingkungan alam dan keselarasan hubungan dengan bangsabangsa. Oleh karena itu tujuan pembangunan adalah meningkatkan kualitas manusia, baik kualitas fisik maupun non fisik. Untuk mencapai tujuan tersebut, maka harus dilaksanakan secara 
bertahap dan diharapkan keikutsertaan atau partisipasi aktif dari seluruh masyarakat di dalamnya karena partisipasi berarti ikut sertanya masyarakat di dalam usaha-usaha pemerintah dalam proses pembangunan, baik bersifat dana, tenaga, atau pikiran. Dari sekian banyak kebijaksanaan pembangunan, salah satunya adalah pembangunan di bidang kesehatan. Masyarakat berhak untuk memperoleh derajat kesehatan yang sama dan berkewajiban ikut serta dalam usaha kesehatan yang diselenggarakan oleh pemerintah. Untuk memperoleh itu semua maka diperlukan berbagai usaha pemenuhan kebutuhan-kebutuhan pokok masyarakat Indonesia, yang pada hakekatnya terpenuhi sandang, pangan, papan, kesehatan dan pendidikan.

Pembangunan kesehatan di Indonesia yang utama ditujukan kepada golongan masyarakat yang berpenghasilan rendah, baik di daerah pedesaan maupun perkotaan. Serta adanya upaya perbaikan kesehatan rakyat antara lain melalui pemberantasan penyakit menular, perbaikan gizi, penyediaan air bersih, kebersihan dan kesehatan lingkungan, serta pelayanan kesehatan ibu dan anak dan pelayanan kesehatan lainnya. Pembangunan kesehatan lingkungan merupakan salah satu bagian dari pembangunan kesehatan masyarakat, Secara konsepsional, kesehatan lingkungan merupakan bagian yang tak terpisahkan dari ilmu kesehatan masyarakat secara utuh. Ini diartikan bahwa untuk keberhasilannya, kesehatan lingkungan tidak dapat diupayakan tersendiri tanpa menjalin secara terintegerasi dengan cabang-cabang upaya kesehatan masyarakat lainnya. Kesehatan lingkungan suatu keseimbangan ekologi yang harus ada antara manusia dan lingkungan agar dapat menjamin keadaan sehat dari manusia. Ruang lingkup kesehatan lingkungan meliputi : penyediaan air minum, pengelolaan air buangan dan pengendalian pencemaran, pembuangan sampah padat, pengendalian hygiene makanan termasuk higine susu, pengadalian pencemaran udara, pemukiman, aspek kesehatan lingkungan dan transportasi udara, perencanaan daerah perkotaan, pencegahan kecelakaan, rekreasi umum dan pariwisata, tindakan-tindakan sanitasi yang berhubungan dengan keadaan epidemic/wabah, bencana alam dan perpindahan penduduk, tindakan pencegahan yang di perlukan untuk menjamin lingkungan

Masalah kesehatan lingkungan suatu masalah yang sangat kompleks, yang saling berkaitan dengan masalah-masalah lain di luar kesehatan itu sendiri. Demikian pemecahan masalah kesehatan masyarakat, tidak hanya di lihat dari segi-segi atau kesehatan tersebut banyak kesehatan individu maupun kesehatan masyrakat, untuk hal ini kesehatan lingkungan pada hakikatnya adalah suatu kondisi atau keadaan lingkungan yang optimum sehingga berpengaruh positif terhadap terwujudnya status kesehatan lingkungan tersebut antara lain mencakup: perumahan, pembuangan kotoran manusia (tinja), penyediaan air bersih, pembuangan sampah, pembuangan air kotor (air limbah), rumah hewan ternak (kandang), dan sebagainya. Agar terwujudnya derajat kesehatan masyarakat yang optimal, pemerintah menyelenggarakan program pembangunan nasional secara berkelanjutan, perencana dan terarah untuk pencapaian tujuan pembangunan kesehatan tersebut diselenggarakan berbagai upaya kesehatan secara menyeluruh, berjenjang dan terpadu, puskesmas berbagai penanggung jawab penyelenggara upaya kesehatan untuk jenjang tingkat pertama. Untuk mengatasi permasalahan kesehatan masyarakat terutama karena meningkatnya penyakit dan/atau gangguan kesehatan yang diakibatkan oleh faktor risiko lingkungan, Pemerintah telah menetapkan Puskesmas sebagai fasilitas pelayanan kesehatan terdepan yang menyelenggarakan upaya kesehatan masyarakat dan upaya kesehatan perorangan tingkat pertama dengan lebih 
mengutamakan upaya promotif dan preventif untuk mencapai derajat kesehatan masyarakat yang setinggi-tingginya di wilayah kerjanya. Dalam pengaturan Puskesmas ditegaskan bahwa salah satu upaya kesehatan masyarakat yang bersifat esensial adalah berupa pelayanan kesehatan lingkungan. Upaya kesehatan masyarakat esensial tersebut harus diselenggarakan oleh setiap Puskesmas untuk mendukung pencapaian standar pelayanan minimal kabupaten bidang kesehatan.

$\begin{array}{lcr}\quad \text { Puskesmas } & \text { selalu berupaya } \\ \text { menggerakkan } & \text { dan } & \text { memantau } \\ \text { penyelenggaraan } & \text { pembangunan lintas }\end{array}$
sektor termasuk oleh masyarakat dan dunia usaha di wilayah kerjanya, sehingga berwawasan serta mendukung pembangunan kesehatan. Di samping itu puskesmas aktif memantau dan melaporkan dampak kesehatan dari penyelenggaraan setiap program pembangunan di wilayah kerjanya. Khusus untuk pembangunan kesehatan, upaya yang dilakukan puskesmas adalah mengutamakan pemeliharaan kesehatan dan pencegahan penyakit tanpa mengabaikan penyembuhan penyakit dan pemulihan kesehatan.Dalam melaksanakan fungsinya, puskesmas berkoordinasi dengan kantor kecamatan melalui pertemuan berkala yang diselenggarakan di tingkat kecamatan. Koordinasi tersebut mencakup perencanaan, penggerakan pelaksanaan, pengawasan dan pengendalian serta penilaian. Dalam hal pelaksanaan fungsi penggalian sumber daya masyarakat oleh puskesmas, koordinasi dengan kantor kecamatan mencakup pula kegiatan fasilitasi. Koordinasi adalah suatu proses untuk mengembangkan dan memelihara hubungan yang baik diantara berbagai kegiatan, baik itu kegiatan-kegiatan fisik maupun kegiatan rohaniah. Koordinasi sangat penting dalam organisasi-organisasi yang kompleks, karena disitu terdapat kegiatan yang berlainan dilakukan oleh banyak orang. Kebutuhan akan koordinasi timbul apabila satu orang atau kelompok bertanggung jawab atas kesempurnaan suatu tugas. Apabila terdapat keadaan saling bergantung diantara kegiatankegiatan tersebut, maka hasil yang efektif akan dapat tercapai hanya apabila kegiatankegiatan tersebut dikoordinasikan.

Koordinasi merupakan kewajiban yang penting untuk menghubungkan berbagai kegiatan dari setiap unit kerja dalam usaha pencapaian tujuan dari suatu organisasi. Dalam setiap usaha dimana terdapat beberapa individu/unit kerja yang mempunyai kesamaan tujuan pasti akan menimbulkan koordinasi (hubungan kerja). Suatu hal yang mustahil akan mencapai tujuan bila tiap individu/unit kerja yang saling terkait berjalan sendiri-sendiri tanpa adanya koordinasi. Koordinasi dalam penelitian ini adalah salah satu usaha kerja sama yang terpadu pemerintah kecamatan dan Puskesmas, untuk melakukan tugastugasnya tertentu sehingga dapat mencapai tujuan yang telah ditentukan bersama. Tujuan yang ingin dicapai dalam pelaksanaan koordinasi adalah agar pelaksanaan tugas berjalan lancar tanpa adanya kesimpangsiuran yang akan memberikan dampak kurang baik terhadap pencapaian tujuan organisasi yang telah ditetapkan. Selain itu dengan koordinasi akan terbina hubungan yang harmonis diantara anggota-anggotanya.

Puskesmas adalah ujung tombak pelayanan kesehatan yang paling dasar dan terdepan dalam mewujudkan komitmen peningkatan mutu pelayanan kesehatan. Salah satu program pokok pelayanan kesehatan di puskesmas adalah pelayanan kesehatan lingkungan, pelayanan yang merupakan program pelayanan kesehatan di puskesmas ditujukan untuk memberikan pelayanan kesehatan kepada kesatuan ruang dengan semua benda, daya keadaan, dan mahluk hidup, termasuk di dalamnya manusia dan perilakunya yang mempengaruhi kehidupan dan kesejahteraan manusia serta makhluk hidup lainnya. Pemerintah kecamatan merupakan pemimpin kecamatan sebagai perangkat daerah kabupaten atau kota. Camat berkedudukan sebagai koordinator 
penyelenggaraan pemerintahan di wilayah kecamatan, berada di bawah dan bertanggung jawab kepada bupati melalui sekretaris daerah kabupaten atau kota. Camat diangkat oleh bupati atau walikota atas usul Sekretaris Daerah atau kota terhadap Pegawai Negeri Sipil yang memenuhi syarat. Mengingat Camat sebagai pimpinan pemerintahan di kecamatan serta sebagai penanggung jawab utama pemerintahan, pembangunan dan masyarakat, maka camat harus mampu berusaha semaksimal mungkin guna mengikutsertakan segala kegiatan pembangunan secara merata dan seimbang dengan memperhatikan segala kesehatan lingkungan. Kesehatan lingkungan yang merupakan bagian dari pada kesehatan masyarakat pada umumnya, mempunyai tujuan membina dan meningkatkan derajat kesehatan dari kehidupan sehari-hari, baik fisik, mental, maupun sosial dengan cara pencegahan terhadap penyakit dan gangguan kesehatan. Begitu pula masalah kesehatan lingkungan di Kecamatan Pagaden Kabupaten Subang yang letak geografisnya berdekatan dengan Kota Subang memerlukan peningkatan dalam menanggulangi masalah tersebut, karena di Kecamatan Pagaden, masalah kesehatan lingkungan masih kurang memenuhi harapan pemerintah dengan permasalahan sebagai berikut : Masih kurangnya tingkat pemahaman sebagian masyarakat tentang hidup sehat sebagian masyarakat di wilayah Kecamatan Pagaden belum dapat melaksanakan Perilaku Hidup Bersih Sehat (PHBS) sepenuhnya, seperti: masih ada masyarakat yang mandi, mencuci dan bab di sungai; dan masih banyak masyarakat buang sampah sembarangan ke sungai; masih kurangnya partisipasi sebagian masyarakat dalam menciptakan lingkungan yang besih dan sehat; dan kurang optimal terwujudnya lingkungan yang sehat di Kecamatan Pagaden secara merata di setiap desa.

\section{METODE}

Penelitian ini menggunakan metode penelitian deskriptif dengan pendekatan kualitatif. Penelitian kualitatif bertujuan untuk menggambarkan secara tepat sifatsifat individu, keadaan, gejala atau kelompok tertentu untuk menentukan adanya suatu gejala dengan gejala lain dalam masyarakat. Penelitian kualitatif sebagai prosedur penelitian yang menghasilkan data deskriptif berupa katakata tertulis atau lisan dari orang-orang dalam perilaku yang dapat diamati. Metode yang digunakan dalam penelitian ini bertujuan untuk mendapatkan data-data berdasarkan keadaan yang ada, hasil wawancara langsung dengan informan dan dari dokumen-dokumen yang ada (Bogdan dan Taylor dalam Moleong, 2005 :3). Penggunaan metode deskriptif dengan pendekatan kualitatif ini memiliki keunggulan karena masalah yang dikaji tidak sekedar berdasarkan laporan pada suatu kejadian ataufenomena saja melainkan juga dikonfirmasi dengan sumber-sumber lain yang relevan. Berdasarkan tujuan penelitian kualitatif, maka prosedur sampling yangpenting adalah bagaimana menemukan informasi kunci (key informant). Orientasi mengenai informan adalah bukan berapa jumlah masyarakat yang dijadikan informan tetapi apakah data yang terkumpul sudah mencukupi atau belum.

Metode penelitian kualitatif digunakan dalam penelitian ini, karena pada umumnya permasalahannya belum jelas, holistik, dinamis, dan penuh makna sehingga tidak mungkin data pada situasi sosial tersebut diperoleh dengan metode penelitian kuantitatif dengan instrumen seperti test, kuesioner. Selain itu peneliti bermaksud memahami situasi sosial secara mendalam, menemukan pola, hipotesis dan teori (Sugiyono, 2010 : 399). Penjelasan diatas dapat disimpulkan bahwa penelitian deskriptif dengan Penelitian deskriptif dengan pendekatan kualitatif mempunyai karakteristik antara lain: berlatar belakang 
alamiah, mengandalkan manusia sebagai obyek penelitian, memanfaatkan data kualitatif, menggunakan analisis secara induktif, mengarahkan sasaran penelitian pada usaha menemukan teori dasar yang bersifat deskriptif, lebih mementingkan pada hasil, membatasi kajian pada fokus tertentu, rancangan penelitiannya bersifat sementara, dan hasil penelitiannya dapat diterima oleh semua pihak. Sehingga bentuk ini dirasa penting dalam penelitian ini.

\section{HASIL DAN PEMBAHASAN}

\section{Koordinasi Puskesmas Dengan Kecamatan Dalam Meningkatkan Kesehatan Lingkungan Di Kecamatan Pagaden}

Kesehatan lingkungan yang merupakan bagian dari pada kesehatan masyarakat pada umumnya, mempunyai tujuan membina dan meningkatkan derajat kesehatan dari kehidupan sehari-hari, baik fisik, mental, maupun sosial dengan cara pencegahan terhadap penyakit dan gangguan kesehatan. Masalah kesehatan lingkungan terutama di Kabupaten Subang pada masa pembangunan ini menjadi masalah yang sangat rumit dan memerlukan pemecahan secara terorganisir. Begitu pula masalah kesehatan lingkungan di Kecamatan Pagaden memerlukan peningkatan dalam menanggulangi masalah tersebut.

Pemerintah kecamatan merupakan pemimpin kecamatan sebagai perangkat daerah Kabupaten. Camat berkedudukan sebagai koordinator penyelenggaraan pemerintahan di wilayah kecamatan, berada di bawah dan bertanggung jawab kepada Bupati melalui Sekretaris Daerah. Camat diangkat oleh bupati atas usul Sekretaris Daerah terhadap Pegawai Negeri Sipil yang memenuhi syarat. Di Kecamatan Pagaden, masalah kesehatan lingkungan masih kurang diperhatikan oleh pemerintah Kabupaten melalui Dinas terkait serta pemerintah Kecamatan. Hal ini terlihat dari masih kurangnya sarana infrastruktur kesehatan seperti Pusat Kesehatan Masyarakat (Puskesmas) yang hanya ada satu yaitu Puskesmas Pagaden. Untuk meningkatkan mutu Pelayanan Kesehatan Lingkungan, setiap Puskesmas harus melakukan pemantauan dan evaluasi pelayanan kesehatan lingkungan. pemantauan dan evaluasi mencakup Pelayanan Kesehatan Lingkungan Puskesmas dan pelaksanaan pengawasan kualitas media lingkungan dalam rangka program kesehatan. Hasil pemantauan dan evaluasi digunakan untuk mengukur kinerja pelayanan kesehatan lingkungan di Puskesmas yang sekaligus menjadi indikator dalam penilaian akreditasi Puskesmas.

Pemantauan dan evaluasi dilakukan untuk memperoleh gambaran hasil Pelayanan Kesehatan Lingkungan di Puskesmas terhadap akses masyarakat untuk memperoleh Pelayanan Kesehatan Lingkungan, kualitas Pelayanan Kesehatan Lingkungan Puskesmas, masalah yang dihadapi, dan dampak kesehatan masyarakat. Kedinamisan organisasi dalam mencapai suatu tujuan adalah dimana terdapat dinamika dalam prosesnya, dimana terdapat aktivitas atau tindakan daripada tata hubungan yang terjadi dalam organisasi itu. Misalnya aktivitas tata hubungan atasan dengan bawahan, tata hubungan antar sesama atasan, dan sesama bawahan. Kemudian bagian-bagian yang saling ketergantungan atau berkaitan untuk membentuk suatu kesatuan yang bulat melalui kewenangan, koordinasi dan pengawasan dalam usaha mencapai tujuan yang telah ditentukan. Terdapat faktorfaktor yang menunjang keberhasilan suatu organisasi menjalankan koordinasinya dengan baik, bagaimana mengendalikan satu individu yang berbeda dengan menyatukannya menjadi satu kesatuan kerja, satu kelompok kerja yang tertata. Seperti yang dikemukakan oleh Hasibuan (2006 : 88) yang merupakan faktor-faktor penunjang koordinasi, terdiri dari : 


\section{Kesatuan Tindakan}

Kesehatan lingkungan memerlukan keterlibatan semua pihak pemerintah maupun dari pihak masyarakat. Kemampuan pemerintah daerah dalam wilayah kecamatan, harus betul-betul ditingkatkan terutama dalam bentuk tindakan dan kebijakan-kebijakan dalam menjalankan perputaran roda pembangunan.

Pemerintah di Kecamatan Pagaden sudah memiliki peran yang aktif dalam mewujudkan kesehatan lingkungan, sehingga Kecamatan ini terlihat lebih bersih, indah dan rapi dari tahun ke tahun. Diharapkan juga sebelum pemerintah menganjurkan masyarakat supaya menjaga lingkungan disekitarnya untuk meningkatkan kesehatan lingkungan, pemerintah haruslah terlebih dahulu mengerti tentang kesehatan lingkungan itu sendiri. Cara atau kegiatan pelaksanaannya, perkembangan dan permasalahan yang dihadapi serta harus bisa memilih strategi atau cara yang sesuai dengan keadaan wilayahnya.

Pelayanan Kesehatan Lingkungan di Puskesmas diarahkan untuk mengendalikan faktor risiko penyakit atau gangguan kesehatan akibat buruknya kondisi kesehatan lingkungan melalui upaya promotif dan preventif, serta spesifik proteksi. Peran Puskesmas selain memberikan pelayanan yang bersifat upaya kesehatan perseorangan, juga pada upaya kesehatan masyarakat melalui Pelayanan Kesehatan Lingkungan, sehingga memperkuat Puskesmas sebagai pusat pembangunan kesehatan terdepan. Dengan demikian peran Puskesmas sangat penting dalam mendukung pembangunan kesehatan yang langsung dirasakan oleh masyarakat.

Pelayanan kesehatan di Puskesmas ini juga menjadi bagian penting dari standar pelayanan minimal kabupaten/kota yang merupakan indikator bagi pemerintah daerah dalam memberikan pelayanan terhadap masyarakatnya. Diharapkan dengan ditetapkannya pengaturan mengenai Penyelenggaraan Pelayanan
Kesehatan Lingkungan di Puskesmas, masyarakat akan semakin mendapat kemudahan akses dari fasilitas pelayanan kesehatan dalam memperoleh kebutuhan untuk mendukung dan meningkatkan derajat kesehatan setinggi-tingginya. Pemerintah Kabupaten Subang khususnya Kecamatan Pagaden dan Puskesmas Pagaden telah berkoordinasi untuk melaksanakan program sesuai dengan tugasnya masing-masing sehingga terwujud lingkungan yang bersih, indah dan sehat. Namun pemerintah juga menyadari masih kurang optimalnya semua program dalam meningkatkan kesehatan lingkungan di Kecamatan Pagaden, karena masih adanya masyarakat yang belum sadar akan arti hidup sehat. Pada hakekatnya koordinasi memerlukan kesadaran setiap anggota organisasi atau satuan organisasi untuk saling menyesuaikan diri atau tugasnya dengan anggota atau satuan anggota organisasi lainnya agar anggota atau satuan organisasi tersebut tidak berjalan sendiri-sendiri. Oleh sebab itu kesatuan tindakan adalah inti dari pada koordinasi. Kesatuan dari pada usaha, berarti bahwa pemimpin harus mengatur sedemikian rupa usaha-usaha dari pada tiap kegiatan individu sehingga terdapat adanya keserasian di dalam mencapai hasil. Kesatuan tindakan ini merupakan suatu kewajiban dari pimpinan untuk memperoleh suatu koordinasi yang baik dengan mengatur jadwal waktu dimaksudkan bahwa kesatuan usaha itu dapat berjalan sesuai dengan waktu yang telah direncanakan.

Untuk mengetahui bagaimana pandangan pemerintah terhadap peranan Puskesmas Pagaden dan pemerintah Kecamatan Pagaden dalam meningkatkan kesehatan lingkungan dapat dilihat dari wawancara dengan Camat Kecamatan Pagaden masalah kesatuan tindakan sebagai berikut: Pihak kecamatan sebagai penerima manfaat misalnya bila ada pihak Puskesmas menyodorkan program kesehatan dalam hal ini kesehatan lingkungan yang membutuhkan dukungan 
kebijakan maka Camat yang mempunyai kewenangan yang lebih besar dari puskesmas akan membantu dalam Pembuatan kebijakan sampai pada pelaksanaan kebijakan tersebut pihak kecamatan melalui Kasie Trantib, Kepala Desa sampai para kader atau RT/RW akan turun tangan untuk mengamankan yang berkenaan dengan hal tersebut. Atau apabila pihak puskesmas membutuhkan bantuan personel dan massa maka pihak kecamatan akan membantu dalam pengerahan personel dan massa untuk mensukseskan program kesehatan tersebut termasuk kesehatan lingkungan. Berikut adalah wawancara penulis dengan Kepala Puskesmas Kecamatan Pagaden ditanyakan tentang kesatuan tindakan dengan pihak Kecamatan dalam pelaksanaan kesehatan lingkungan sebagai berikut: Apabila puskesmas mempunyai Program kesehatan maka akan di koordinasikan dengan pihak kecamatan melalui Kasie Kessos. Untuk memberikan dukungan berupa kebijakan karena secara teknis kami yang bekerja namun pihak puskesmas juga selalu melibatkan tim yang ada di kecamatan untuk membantu Program kesehatan tersebut. Pertanyaan serupa ditanyakan kepada Petugas Kesehatan Lingkungan Puskesmas Pagaden, dengan hasil jawaban sebagai berikut : Program-program kesehatan yang ada di puskesmas terutama program kesehatan lingkungan tidak dapat dilakukan sendirian oleh Petugas Kesling sehingga dalam pelaksanaanya selalu melibatkan pihak kecamatan yang mempunyai kebijakan begitu pula apabila ada program di kecamatan yang berkenaan dengan Kesehatan seperti contohnya ada bantuan fisik MCK atau saraana penyediaan air bersih mereka melibatkan pihak puskesmas. Sehingga ada kesatuan kerja yang saling mendukung. Dari hasil wawancara dan observasi penulis menganalisis bahwa konsep kesatuan tindakan yaitu adanya kerjasama antar lembaga instansi terkait, selain adanya kerjasama antar instansi terkait dan juga kesadaran setiap anggota organisasi dalam melaksanakan kerjasama. Pada koordinasi dalam penanganan kesehatan lingkungan sudah ada kesatuan tindakan, hal ini terbukti dengan adanya kerjasama antara Puskesmas Pagaden dan Kantor Kecamatan Pagaden dalam sosialisasi program kesehatan lingkungan kepada masyarakat, karena program kesehatan lingkungan tidak akan berjalan dengan baik bila tidak melibatkan unsur birokrasi di tingkat paling bawah. Menurut informan juga mengatakan bahwa dalam pelaksanaan untuk mewujudkan kualitas lingkungan yang sehat dan mencegah penyakit atau gangguan kesehatan dari faktor risiko lingkungan serta dalam rangka mendukung pencapaian standar pelayanan minimal bidang kesehatan, perlu diselenggarakan pelayanan kesehatan lingkungan di Puskesmas yang diwujudkan dalam Peraturan Menteri Kesehatan Republik Indonesia Nomor 13 Tahun 2015 Tentang Penyelenggaraan Pelayanan Kesehatan Lingkungan di Puskesmas. Dalam rangka melaksanakan program kesehatan, pengawasan kualitas media lingkungan secara berkala, atau penanggulangan kejadian luar biasa, tenaga kesehatan lingkungan di Puskesmas harus melakukan inspeksi kesehatan lingkungan dan intervensi kesehatan lingkungan pada permukiman, tempat kerja, dan fasilitas umum sesuai dengan ketentuan peraturan perundang-undangan. Untuk meningkatkan kesehatan lingkungan, Camat beserta Puskesmas Pagaden secara berkala senantiasa mengadakan penyuluhan kepada masyarakat baik secara langsung, misalnya dengan cara memberikan penerangan di lingkungan secara bergilir atau rutin, sedangkan secara tidak langsung misalnya dengan cara membuat larangan-larangan penggunaan tempat-tempat tertentu yang dianggap mengganggu kesehatan khususnya kesehatan lingkungan antara lain, misalnya larangan tidak boleh membuang sampah atau kotoran di sembarang tempat dan sebagainya.

Penyuluhan ini penting mengingat kehidupan sosial masyarakat senantiasa 
berubah dan dalam memberikan penyuluhan hendaknya selalu menyesuaikan dengan situasi dan kondisi masyarakat, sehingga tidak menimbulkan kesan yang pada akhirnya membawa hasil sebagaimana yang diharapkan. Bentuk bimbingan dan penyuluhan ini kiranya dianggap penting adanya mengingat kehidupan masyarakat desa dilatar belakangi oleh faktor sosial ekonomi dan sosiologi sehingga senantiasa membuat kehidupan masyarakat kelurahan antara satu dengan yang lainnya senantiasa berbeda pula. Pelaksanaan penyuluhan kepada masyarakat haruslah merupakan interaksi aktif dari kedua belah pihak. Disamping itu seharusnya terjalin pula suatu komunikasi dua arah antara pemerintah dengan masyarakat sebagai perwujudan adanya hubungan yang harmonis antara masyarakat dan pemerintah. Pemberian penyuluhan tersebut sebaiknya tidak dilaksanakan secara intensif yang nantinya menimbulkan eksis berlebihan bagi masyarakat kelurahan, tetapi sebaiknya dilaksanakan pemberian penyuluhan dilaksanakan secara rutin dan berkala, sebab hal tersebut suatu proses pembelajaran bagi masyarakat yang akan memakan rentang waktu yang cukup lama. Mengingat faktor sosial ekonomi dan sosiologis dalam kehidupan masyarakat kelurahan sangat mempengaruhi kesanggupan masyarakat tersebut.

Masalah kesehatan merupakan salah satu bentuk pemasalahan yang harus ditangani baik oleh pemerintah maupun masyarakat itu sendiri. Mengingat pentingnya kesehatan tersebut, UndangUndang Nomor 36 Tahun 2009 memberikan arah sebagai berikut :

1. Kesehatan sebagai salah satu unsur kesejahteraan umum harus diwujudkan sesuai dengan cita-cita bangsa Indonesia sebagaimana dimaksud dalam Pembukaan UndangUndang Dasar 1945 melalui pembangunan Nasional yang berkesinambungan berdasarkan
Pancasila dan Undang-Undang Dasar 1945

2. Pembangunan kesehatan diarahkan untuk mempertinggi derajat kesehatan, yang besar artinya bagi pengembangan dan pembinaan sumber daya manusia Indonesia dan sebagai modal bagi pelaksanaan pembangunan nasional yang ada hakikatnya adalah pembangunan manusia Indonesia seutuhnya dan pembangunan seluruh masyarakat Indonesia.

Dari hasil observasi yang dilakukan oleh penulis terhadap aktifitas keseharian masyarakat, maka faktor-faktor yang berpengaruh dalam meningkatkan kesehatan lingkungan keluarga di Kecamatan Pagaden dapat diklasifikasikan menjadi dua bagian yaitu, faktor-faktor positif atau faktor yang mendukung terhadap peningkatan kesehatan lingkungan, dan faktor negatif atau faktor yang menghambat peningkatan kesehatan lingkungan

Untuk suksesnya pelaksanaan pelaksanaan kesehatan lingkungan yang dilaksanakan oleh Puskesmas Pagaden dan pemerintahan Kecamatan Pagaden di desadesa, maka terhadap semua lembaga pemerintahan maupun lembaga kemasyarakatan diperlukan adanya koordinasi yang baik agar dapat ikut berperan serta dalam pemerintahan atau pembangunan. Hal ini diperlukan berdasarkan kepada suatu prinsip bahwa suksesnya suatu pemerintahan tidak hanya ditentukan oleh perangkat pemerintahan itu sendiri tetapi juga oleh peran serta masyarakat didalam mendukung pelaksanaan pemerintahan tersebut. Demikian pula halnya yang terjadi di Kecamatan Pagaden lembaga kemasyarakatan yanga ada di Kecamatan tersebut senantiasa berperan aktif dalam menyukseskan setiap program pemerintah khususnya pemerintahan di desa dalam rangka peningkatan kesehatan lingkungan. Hal ini mereka lakukan dengan cara melibatkan diri atau terjun langsung di lapangan dengan mengadakan kerja bakti, 
membantu kerja kesehatan lingkungan, memperbaiki jalan yang rusak agar tidak tergenang air, serta menanam pohon ataupun bunga ditepi jalan.

Jadi kesatuan tindakan adalah penyatuan tindakan yang diatur oleh pimpinan untuk menciptakan keserasian dalam mencapai suatu tujuan. Hal ini bisa dilihat dari tanpa adanya kesatuan tindakan antara Puskesmas Pagaden dan kantor Kecamatan Pagaden, usaha pelaksanaan penanganan kesehatan lingkungan akan sulit dilakukan. Dalam suatu kegiatan perlu adanya kerjasama yang saling pengertian dari setiap personil instansi yang terkait dalam penanganan kesehatan lingkungan baik berupa koordinasi melalui kewenangan, pedoman kerja forum. Jadi koordinasi yang tercipta akan berjalan sebagaimana mestinya karena kerjasama yang saling pengertian akan menghasilkan koordinasi yang baik, hal ini terbukti dengan adanya kerjasama antara Puskesmas Pagaden dan Kantor Kecamatan Pagaden dalam sosialisasi Peraturan Menteri Kesehatan Republik Indonesia Nomor 13 Tahun 2015 Tentang Penyelenggaraan Pelayanan Kesehatan Lingkungan di Puskesmas, sosialisasi tersebut merupakan wewenang dari kedua instansi tersebut.

\section{Komunikasi}

Kesehatan merupakan keadaan sejahtera dari badan, jiwa dan sosial yang memungkinkan setiap orang hidup produktif secara sosial dan ekonomi. Karena itu, kesehatan adalah unsur yang paling penting dalam hidup manusia. Kesehatan erat kaitannya dengan kondisi ekonomi. Ekonomi yang mapan dengan sendirinya akan menciptakan kondisi kesehatan yang baik maka faktor-faktor yang mempengaruhi kesehatan manusia seperti makanan dan minuman yang sehat, lingkungan yang sehat dan kebiasaan hidup yang sehat akan terpenuhi. Sebaliknya ekonomi yang buruk akan menyulitkan individu masyarakat untuk memenuhi beberapa faktor di atas, dimana jika kondisi tersebut dipelihara maka individu masyarakat akan kesulitan memperbaiki kesehatan mereka masing-masing

Masalah kesehatan lingkungan yang timbul terutama disebabkan oleh lingkungan yang kurang atau tidak memenuhi syarat kesehatan dan belum terpenuhinya kebutuhan sanitasi dasar seperti penyediaan air bersih, pembuangan sampah, sarana pembuangan air limbah dan pembuangan tinja. Oleh karena itu pemerintah memprioritaskan peningkatan kesehatan lingkungan. Puskesmas adalah ujung tombak pelayanan kesehatan yang paling dasar dan terdepan dalam mewujudkan komitmen peningkatan mutu pelayanan kesehatan. Melalui program pelayanan puskesmas, diharapkan akan tercapai masyarakat yang mandiri menuju sehat sesuai dengan visi Departemen kesehatan program puskesmas terdiri dari program kesehatan dasar yaitu program promosi kesehatan, Program kesehatan lingkungan, Program keluarga berencana, program pemberantasan penyakit menular, Program peningkatan gizi, Program kesehatan ibu dan anak, Program pengobatan, Program kesehatan pengembangan yaitu Program penyuluhan kesehatan masyarakat, program labotarium, program kesehatan sekolah, program perawatan kesehatan masyarakat, program kesehatan jiwa, dan program kesehatan gigi (Mubarak, 2009 : 89).

Salah satu program pokok pelayanan kesehatan di puskesmas adalah pelayanan kesehatan lingkungan, pelayanan yang merupakan program pelayanan kesehatan di puskesmas ditujukan untuk memberikan pelayanan kesehatan kepada kesatuan ruang dengan semua benda, daya keadaan, dan mahluk hidup, termasuk di dalamnya manusia dan perilakunya yang mempengaruhi kehidupan dan kesejahteraan manusia serta makhluk hidup lainnya. (Depkes, 2004 : 4). Untuk melaksanakan program pokok pelayanan kesehatan lingkungan agar berjalan sesuai dengan rencana, maka pihak puskesmas menjalin komunikasi dengan 
pihak birokrasi yaitu pihak kecamatan. Komunikasi tidak dapat dipisahkan dari koordinasi, karena komunikasi sejumlah unit dalam organisasi akan dapat dikoordinasikan berdasarkan rentang dimana sebagian besar ditentukan oleh adanya komunikasi. Komunikasi merupakan salah satu dari sekian banyak kebutuhan manusia dalam menjalani hidup dan kehidupannya. Kata komunikasi berasal dari kata communicare, yaitu dalam bahasa latin mempunyai arti berpartisipasi ataupun memberitahukan. Dalam organisasi komunikasi sangat penting karena dengan komunikasi partisipasi anggota akan semakin tinggi dan pimpinan memberitahukan tugas kepada bawahan harus dengan komunikasi. Dengan demikian komunikasi merupakan hubungan antara komunikator dengan komunikan dimana keduanya mempunyai peran dalam menciptakan komunikasi.

Berikut adalah wawancara penulis dengan Camat Kecamatan Pagaden ditanyakan tentang cara mengumpulkan dan menyebarkan informasi mengenai penanganan kesehatan lingkungan, sebagai berikut: Kecamatan mempunyai aparat yang ada di daerah yang dapat dikerahkan sesuai kebutuhan dan ada ada kader-kader yang ada di daerah yang sering terlibat dalam kegiatan-kegiatan yang dilaksanakan Puskesmas mereka-mereka ini setia dan bisa berkoordinasi dengan puskesmas melalui kegiatan- kegiatan posyandu atau bahkan menghadiri pertemuan-pertemuan seperti lokakarya mingguan dan bulanan yang di selenggarakan oleh pihak puskesmas

Berikut adalah wawancara penulis dengan Kepala Puskesmas Pagaden ditanyakan tentang cara mengumpulkan dan menyebarkan informasi mengenai penanganan kesehatan lingkungan, sebagai berikut: Puskesmas pagaden menggerakkan semua unsur yang ada di Puskesmas Pagaden untuk mengumpulkan dan menyebarkan informasi mengenai peningkatan kesehatan linkungan seperti halnya petugas kesling yang sering mengikuti musrengbang yang dilaksanakan oleh pihak kecamatan pagaden. Juga para bidan desa yang setiap harinya bekerja di tiap desa menyampaikan laporan secara berkala dalam Lokakarya mingguan dan bulanan yang diselenggarakan oleh Puskesmas Pagaden sehingga ada koordinasi lintas program dengan di tiap program yang ada di puskesmas binong termasuk program Kesehatan lingkungan . Hasil wawancara di atas didukung oleh hasil wawancara penulis dengan Petugas Kesling Puskemas Pagaden yang menyatakan : Kami sebagai Petugas program kesehatan lingkungan selalu menghadiri kegiatan yang dilaksanakan pihak kecamatan bahkan jemput bola ke lapangan untuk menggali informasi dan menyebarkannya. Pengumpulan informasi tentang kesehatan lingkungan pihak puskesmas melibatkan semua unsur yang ada di puskesmas dengan cara kerjasama lintas program dengaan program yang ada di puskesmas Pagaden seperti Program Promkes atau program-program lainnya. Berdasarkan hasil wawancara tersebut di atas dan hasil observasi dapat disimpulkan bahwa pelaksanaan program kesehatan lingkungan yang dilaksanakan oleh Puskemas Pagaden berjalan sesuai dengan rencana, yaitu pihak puskesmas dapat berkomunikasi dengan pihak kecamatan yang dapat dilihat dengan dukungan yang diberikan oleh pihak birokrasi berupa keterlibatan unsur birokrasi dan masyarakat dalam kegiatan-kegiatan yang dilaksanakan Puskesmas. Mereka bisa berkoordinasi dengan puskesmas melalui kegiatankegiatan posyandu atau bahkan menghadiri pertemuan-pertemuan seperti lokakarya mingguan dan bulanan yang di selenggarakan oleh pihak puskesmas.

Oleh karena itu partisipasi masyarakat dalam pelaksanaan program kesehatan lingkungan sangat penting perannya dalam penyelenggaraan program tersebut. Demikian pula peran dan kerjasama dengan sektor pemerintah yang terkait, seperti Dinas Kesehatan, dan lainlain dalam melaksanakan program 
kesehatan lingkungan harus terbangun dengan baik. Hal ini karena penyelenggara layanan yang diselenggarakan oleh dinas/instansi pemerintah yang berbeda dan mempunyai kebijakan prosedur operasional yang berbeda pula. Tanpa ada kerjasama dan komunikasi yang baik dan, maka program kesehatan lingkungan tidak akan berjalan secara optimal.

Koordinasi antara Puskesmas Pagaden dan pihak Kecamatan Pagaden merupakan faktor utama dalam keberhasilan program kesehatan lingkungan agar berjalan dengan baik. Untuk itu diperlukan mekanisme yang jelas tentang tanggungjawab masing-masing pihak. Hal ini akan sangat terkait dengan otonomi daerah, khususnya yang terkait dengan kewenangan, penganggaran, dan kelembagaan, sehingga diharapkan dengan kejelasan kewenangan masing-masing pihak akan memberi harapan yang besar bagi keberhasilan program kesehatan lingkungan. Koordinasi yang efektif tergantung pada komunikasi yang efektif pula, seperti halnya pemberian informasiinformasi yang dibutuhkan pegawai, informasi tentang pelaksanaan tugas dan pejelasan tugas yang akan dilakukan oleh bawahan yang semuanya di pegang oleh pimpinan. Bentuk koordinasi dapat juga dilihat dari pertemuan melalui rapat koordinasi yang dilakukan oleh Puskesmas dan kantor Kecamatan Pagaden baik secara intern maupun ekstern.

Dalam pelaksanaan suatu koordinasi, sangatlah diperlukan suatu komunikasi yang lancar antara Puskesmas dan kantor Kecamatan Pagaden agar terjalain suatu hubungan kerja sama yang harmonis guna kelancaran dalam penanganan program kesehatan lingkungan sesuai dengan keinginan bersama. Dimana komunikasi merupakan alat untuk memperlancar kegiatan pelaksanaan koordinasi yang dilakukan oleh pihak terkait dalam program kesehatan lingkungan. Di harapkan dengan adanya komunikasi ini dapat mengurangi kesalahpahaman dan kesamaan kerja yang dilakukan setiap anggota dan seluruh pihak terkait pelaksanaan program kesehatan lingkungan.

\section{Pembagian Kerja}

Kesehatan lingkungan suatu keseimbangan ekologi yang harus ada antara manusia dan lingkungan agar dapat menjamin keadaan sehat dari manusia. Ruang lingkup kesehatan lingkungan meliputi : penyediaan air minum, pengelolaan air buangan dan pengendalian pencemaran, pembuangan sampah padat, pengendalian hygiene makanan termasuk higine susu, pengadalian pencemaran udara, pemukiman, aspek kesehatan lingkungan dan transportasi udara, perencanaan daerah perkotaan, tindakantindakan sanitasi yang berhubungan dengan keadaan epidemic/wabah, bencana alam dan perpindahan penduduk, tindakan pencegahan yang diperlukan untuk menjamin lingkungan. (Ghandi, 2010 : 34).

Masalah kesehatan lingkungan suatu masalah yang sangat kompleks, yang saling berkaitan dengan masalah-masalah lain di luar kesehatan itu sendiri.demikian pemecahan masalah kesehatan masyarakat, tidak hanya dilihat dari segi-segi atau kesehatan tersebut.banyak kesehatan individu maupun kesehatan masyarakat, untuk hai ini kesehatan lingkungan pada hakikatnya adalah suatu kondisi atau keadaan lingkungan yang optimum sehingga berpengaruh positif terhadap terwujudnya status kesehatan lingkungan tersebut antara lain mencakup: perumahan, pembuangan kotoran manusia (tinja), penyediaan air bersih, pembuangan sampah, pembuangan air kotor (air limbah), rumah hewan ternak (kandang), dan sebagainya.

Adapun yang dimaksud dengan usaha kesehatan lingkungan adalah suatu usaha untuk memperbaiki atau mengoptimumkan lingkungan hidup manusia agara merupakan media yang baik untuk terwujudnya kesehatan yang optimum bagi manusia yang di dalamnya usaha memperbaiki atau meningkatkan 
kondisi lingkungan dari masa ke masa, dan dari masyarakat satu ke masyarakat yang lain bervariasi dan bertingkat-tingkat, dari usaha yang paling sederhana (primitive) sampai pada paling mutakhir (modern), dengan kata lain bahwa teknologi di bidang kesehatan lingkungan sangat bervariasi dari teknologi primitive, teknologi menengah (teknologi tepat guna) sampai dengan teknologi mutakhir.

Berikut adalah wawancara penulis dengan Camat Kecamatan Pagaden mengenai cara pembagian kerja dan kewenangan dalam pelaksanaan program kesehatan lingkungan sebagai berikut: Pembagian kerja secara spesifik ada di wilayah kewenangan puskesmas pihak kecamatan hanya berkoordinasi apabila ada kejadian seperti demam berdarah dan lain-lain baru jalur birokrasi dibuka dengan pengerahan aparat yang ada di daerah implementasinya Pihak kecamatan hanya sebatas membuat kebijakan seperti pembuatan Surat Keputusan dan Surat Perintah dan secara teknis ada pihak puskesmas. Dari hasil wawancara penulis dengan salah Kepala Puskesmas Pagaden yang menyatakan sebagai berikut: Puseksmas Pagaden hanya berkoordinasi dengan pihak kecamatan yang sifatnya penyuluhan tidak ada pembagiaan kerja secara berstruktur dan sebaliknya Pihak kecamatan akan berkoordinasi dengan Puskesmas apabila ada bantuan fisik baik itu berupa bantuan MCK atau Jamban dan kewenangan Puskesmas hanya mensosialisasiakan bantuan tersebut kepada masyarakat yang mendapatkan bantuan kemudian mendata siapa-siapa saja pihak yang mendapatkan bantuan tersebut. Hasil wawancara tersebut di atas ada kesamaan pendapat dengan salah seorang Petugas Kesling Puskemas Pagaden yang menyatakan : Pihak puskesmas hanya memberikan penyuluhan kearah sikap dan perilaku hidup bersih dan sehat juga mengumpulkan data tentang Kesehatan lingkungan yang ada di wilayah kerja Puskesmas Pagaden untuk disampaikan kepada Pihak Kecamatan agar ditindak lanjuti melalui ranah kebijakan baik itu berupa bantuan fisik atau dukungan kebijakan dan produk peraturan. Berdasarkan hasil wawancara dan observasi penulis menganalisis bahwa pembagian kerja antara Puskesmas dan Kecamatan dalam pelaksanaan program kesehatan lingkungan secara spesifik kewenangan puskesmas dan kecamatan hanya berkoordinasi apabila ada kejadian seperti demam berdarah dan lain-lain baru jalur birokrasi dibuka dengan pengerahan aparat yang ada di daerah pelaksananya pihak kecamatan hanya sebatas membuat kebijakan seperti pembuatan Surat Keputusan dan Surat Perintah dan secara teknis ada pihak puskesmas.

Dalam koordinasi pelaksanaan program kesehatan lingkungan tersebut sangat penting setiap petugas mengetahui tugas masing-masing dalam hal ini adanya pembagian tugas antara Puskesmas Pagaden dan pihak Kecamatan Pagaden, adanya pengetahuan pembagian tugas yang sesuai dengan kemampuan dan bidangnya. Sehingga ketika dilakukan penanganan kasus, mereka sudah memiliki tanggung jawab masing-masing terhadap pekerjaannya. Karena untuk turun ke lapangan itu tidak hanya kesiapan fisik saja yang dibutuhkan tetapi kemampuan terhadap tanggung jawab yang diberikan juga penting. Agar di lapangan mampu untuk mengatasi masalah yang dihadapi, termasuk dalam hal ini adanya rincian atau uraian tugas. Untuk mengetahui apakah setiap anggota yang ikut pelaksanaan mengetahui tugasnya masing-masing. Saat ini banyak sekali permasalah lingkungan yang harus di hadapi dan sangat menggangu terhadap tercapainya kesehatan lingkungan. Perilaku yang kurang baik dari manusia telah mengakibatkan perubahan ekosistem dan timbulnya permasalahan sanitasi.dari sudut pandang biologisnya, lingkungan merupakan tempat berbahaya. Perjuangan hidup dan mati antar-spesies untuk memperoleh makanan, air, dan tempat berlindung berlangsung setiap saat setiap harinya.masing masing spesies yang 
hidup memiliki musuh alaminya sendiri predator, parasit, dan agnes penyakit yang dapat di kelompokan sebagai bahaya biologis. Masyarakat juga berhadapan dengan resiko yang sama besarnya dengan resiko yang di hadapi seorang. (Fauziah, 2012).

Dari hasil observasi di atas dapat disimpulkan bahwa secara teoritis tujuan dalam suatu organisasi adalah untuk mencapai tujuan bersama dimana individu tidak dapat mencapainya sendiri. Kelompok dua atau lebih orang yang berkerja bersama secara kooperatif dan dikoordinasikan dapat mencapai hasil lebih daripada dilakukan perseorangan. Dalam suatu organisasi, tiang dasamya adalah prinsip pembagian kerja (Division of labor). Prinsip pembagian kerja ini adalah maksudnya jika suatu organisasi diharapkan untuk dapat berhasil dengan baik dalam usaha mencapai tujuanya, maka hendaknya lakukan pembagian kerja. Dengan pembagian kerja ini diharapkan dapat berfungsi dalam usaha mewujudkan tujuan suatu organisasi. Pembagian kerja adalah perincian tugas dan pekerjaan agar setiap individu dalam organisasi bertanggung jawab untuk melaksanakan sekumpulan kegiatan yang terbatas.

Jadi pembagian kerja pekerjaan menyebabkan kenaikan efektifitas secara dramatis, karena tidak seorangpun secara fisik mampu melaksanakan keseluruhan aktifitas dalam tugastugas yang paling remit clan tidak seorangpun juga memiliki semua keterampilan yang diperlukan untuk melaksanakan berbagai tugas. Oleh karena itu perlu diadakan pemilahan bagian-bagian tugas dan membagi baginya kepada sejumlah orang. Pembagian pekerjaan yang dispesialisasikan seperti itu memungkinkan orang mempelajari keterampilan dan menjadi ahli pada fungsi pekerjaan tertentu.

\section{Disiplin}

Pada setiap organisasi yang kompleks, setiap bagian harus bekerja secara terkoordinasi, agar masing-masing dapat menghasilkan hasil yang diharapkan.
Koordinasi adalah usaha penyesuaian bagian-bagian yang berbeda-beda agar kegiatan dari pada bagian-bagian itu selesai pada waktunya, sehingga masing-masing dapat memberikan sumbangan usahanya secara maksimal agar diperoleh hasil secara keseluruhan, untuk itu diperlukan disiplin. Dalam suatu organisasi penerapan peraturan kepada seseorang atau anggota organisasi dikelola oleh pimpinan. Pimpinan diharapkan mampu menerapkan konsep disiplin positif yakni penerapan peraturan melalui kesadaran bawahannya. Sebaliknya bila pimpinan tidak mampu menerapkan konsep disiplin positif pada dirinya sendiri tentu dia juga tidak mungkin mampu menerapkannya pada orang lain termasuk kepada bawahannya. Dengan demikiam disiplin itu sangat penting artinya dalam proses pencapaian tujuan, ini merupakan suatu syarat yang sangat menentukan dalam pencapaian tujuan yang dimaksud.

Koordinasi yang baik juga didukung dengan adanya kedisiplinan dari setiap anggota dalam menjalankan tugas. Kedisiplinan diperlukan untuk mempercepat pencapain tugas tanpa adanya kedisplinan dalam setiap pelaksanaan program kesehatan lingkungan tidak dapat terlaksana dengan baik. Berikut adalah wawancara penulis dengan Camat Kecamatan Pagaden mengenai caranya menerapkan aturan agar setiap anggota tim dalam pelaksanaan program kesehatan lingkungan dapat disiplin menjalankan tugas sebagai berikut: Dalam pembuatan kebijakan pihak kecamatan melibatkan semua unsur yang ada di kecamatan sesuai bidang kerjanya mereka bekerja sesuai tugasnya seperti adminstrasi ada di pelayanan umum kebijakan pembuataj SK dan SP ada di Seksi Pemerintahan dan yang lansung berkoordinasi dengan Puskesmas adalah Seksi Kesos yang membawahi bidang agama pendidikan dan kesehatan. Aspek yang berkaitan dengan disiplin informan dalam hal ini pihak Puskesmas Pagaden diberikan pertanyaan mengenai apakah sudah memiliki kesadaran yang 
tinggi dalam menerapkan aturan agar setiap anggota tim dalam pelaksanaan program kesehatan lingkungan. Dari hasil wawancara, diskusi dan analisis sebagian besar informan mengatakan bahwa sudah memiliki kesadaran yang tinggi dalam menjalankan tugas dan fungsi sesuai dengan kewenangan nya serta dalam penindakan pun dilakukan tepat waktu dan menjalankan setiap tugas sesuai dengan prosedur, dengan hasil jawaban sebagai berikut: Kegiatan yang melibatkan pihak Kecamatan dalam pelaksanaanya tidak menerapkan aturan yang baku semua berjalan di atas kesadaran masing-masing anggota tim yang merasa bahwa semua itu adalah sudah menjadi bagian dari tugas yang harus dilaksanakan dengan penuh tanggaung jawab

Hasil wawancara tersebut di atas sejalan dengan hasil jawaban dari salah seorang Petugas Kesling Puskemas Pagaden yang menyatakan. Penerapan aturan secara tertulis tidak ada hanya menanamkan kesadaran pada anggota tim untuk menjalankan masing-masing tugasnya agar dapat terlaksananya program-program kesehatan, yang diantaranya adalah program kesehatan lingkungan dengan hasil yang memuaskan. Berdasarkan hasil analisis penulis bahwa informasi yang disampaikan informan, bahwa kesadaran dan kesediaan anggota dalam menjalankan tugas dapat mendukung koordinasi yang baik antara instansi terkait. Kesadaraan akan tugas yang diberikan kepada Puskesma Pagaden dan Kantor Kecamatan Pagaden serta kesediaan untuk menjalankan tugas hal yang sangat dituntut untuk pencapaian tujuan. Tanpa adanya kesadaran dan kesediaan setiap anggota pelaksanaan program kesehatan lingkungan.

Petugas puskesmas berusaha merubah prilaku hidup masyarakat yang tadinya jauh dari kata sehat lingkungan menjadi selalu menjaga kesehatan lingkungan sehingga terhidar dari penyakit menular. Perilaku hidup bersih warga masyarakat dapat diwujudkan dengan baik apabila sebagian besar warga masyarakat menyadari akan pentingnya lingkungan yang bersih terbebas dari sampah dan kotoran-kotoran lainnya. Hal ini dapat dilakukan dengan meningkatkan kemauan dan kesadaran untuk saling bekerjasama saling mendukung perilaku-perilaku hidup bersih diantara warga anggota masyarakat lainnya. Warga masyarakat dapat menunjukkan perilaku hidup bersih ini juga dengan menjalankan menjaga lingkungan terutama sanitasi lingkungan sekitar rumah masing-masing dan membuang sampah pada tempatnya, memasukkan sampah sisa masakannya pada kantong plastik dan dibuang ditempat yang telah ditentukan atau juga dengan menyelenggarakan serta berpartisipasi dalam kegiatan kerja bakti yang minimal dilakukan minimal satu kali dalam sebulan.

Upaya-upaya bersama antara pihak Puskesma dan Kecamatan yang dapat dilakukan untuk meningkatkan perilaku hidup warga masyarakat juga sangat diperlukan dengan saling mendorong satu sama lain dalam mengingatkan untuk selalu menjaga kebersihan di lingkungan pemukiman. Warga masyarakat telah melakukan kerja bakti dan gotong royong pada suatu waktu tertentu yang telah ditentukan, meski memang secara kualitas dan kuantitas masih perlu ditingkatkan lebih balk lagi. Menurut hasil wawancara bahwa perilaku yang tidak bersih masih sering juga ditemukan dilakukan oleh sebagian kecil anggota masyarakat. Perilaku tidak bersih yang masih ditemukan antara lain adalah buang sampah sembarangan, sanitasi rumah yang buruk dan membiarkan rumput tumbuh liar di pekarangan rumah atau di jalan-jalan gang depan rumah serta tidak memiliki tempat sampah di rumah yang memadai untuk menampung sampah yang banyak. Padahal manfaat yang dapat diperoleh bagi lingkungan dan masyarakat dari terciptanya perilaku hidup bersih sangatlah besar jika dapat terwujudkan dengan baik.

Adapun kegiatan-kegiatan bersama yang sering atau sudah diselenggarakan di 
lingkungan pemukiman antara lain adalah bergotong-royong merapihkan jalanan, menata sanitasi lingkungan (jemantik), dan posyandu ataupun pengajian serta kerja bakti. Namun demikian sering juga dilakukan kegiatan-kegiatan yang ada kaitannya dengan kebersihan masyarakat yakni dengan melakukan kerja bakti membersihkan lingkungan dan terutama menjaga agar tetap terpelihara lingkungan yang nyaman. Partisipasi warga masyarakat terhadap pelaksanaan kegiatan bakti untuk meningkatkan kesehatan lingkungan sebagian besar dapat dikatakan baik yakni sekitar $70 \%$ anggota masyarakat pernah berpartisipasi dalam kegiatan meningkatkan kesehatan lingkungan yang dilakukan secara bersama-sama karena mayoritas warga masyarakat sangat mendukung dengan diadakannya kegiatan-kegiatan bakti sosial dan terutama yang berkaitan dengan upaya meningkatkan perilaku hidup bersih masyarakat. Mengenai kegiatan kerja bakti masih sering dilakukan oleh warga hanya untuk lingkungan sekitar warga pemukiman dan belum meluas pada kegiatan-kegiatan yang dilakukan untuk fasilitas publik seperti sekolah maupun masjid.

Mengenai hambatan-hambatan yang menyebabkan kegiatan bakti sosial untuk meningkatkan perilaku hidup bersih warga masyarakat sehingga tidak dapat terselenggara dengan baik antara kemungkinan disebabkan oleh faktor komunikasi karena informasi tidak jalan, sarana, fasilitator karena tidak ada pemimpin atau juga karena warga merasa tidak membutuhkan kegiatan-kegiatan tersebut. Selain itu kurang berhasilnya penyelenggaraan kegiatan-kegiatan yang bersifat umum atau bersama-sama serta kerja bakti mungkin pula disebabkan oleh kesibukan masing-masing warga yang pada hari libur karena banyak urusan keluarga dan pemahaman warga yang kurang baik akan pentingnya kegiatan bersama seperti kerja bakti misalnya.

Adapun mengenai upaya untuk membentuk perilaku hidup bersih masyarakat yang dilakukan dengan menyelenggarakan kegiatan-kegiatan sosial kemasyarakatan diusahakan dengan melakukan penyuluhan-penyuluhan, pelatihan untuk menciptakan kader-kader masyarakat dan secara rutin melakukan rapat-rapat pengurus untuk pembinaan kebersihan lingkungan sehingga dapat menanamkan kesadaran dan kebiasaan untuk selalu peduli pada lingkungan yang sehat dan nyaman.

\section{SIMPULAN}

Berdasarkan hasil penelitian yang penulis lakukan mengenai Koordinasi Puskesmas Dengan Kecamatan dalam Meningkatkan Kesehatan Lingkungan di Kecamatan Pagaden sudah dijalankan dan hal ini disimpulkan sebagai berikut :

\section{Kesatuan Tindakan}

Pada koordinasi dalam penanganan kesehatan lingkungan sudah ada kesatuan tindakan, hal ini terbukti dengan adanya kerjasama antara Puskesmas Pagaden dan Kantor Kecamatan Pagaden dalam sosialisasi program kesehatan lingkungan kepada masyarakat, karena program kesehatan lingkungan tidak akan berjalan dengan baik bila tidak melibatkan unsur birokrasi di tingkat paling bawah.

\section{Komunikasi}

Pelaksanaan program kesehatan lingkungan yang dilaksanakan oleh Puskemas Pagaden berjalan sesuai dengan rencana, yaitu pihak puskesmas dapat berkomunikasi dengan pihak kecamatan yang dapat dilihat dengan dukungan yang diberikan oleh pihak birokrasi berupa keterlibatan unsur birokrasi dan masyarakat dalam kegiatan-kegiatan yang dilaksanakan Puskesmas.

Pembagian Kerja

Pembagian kerja antara Puskesmas dan Kecamatan dalam pelaksanaan program kesehatan lingkungan secara spesifik kewenangan puskesmas dan kecamatan hanya berkoordinasi apabila ada kejadian seperti demam berdarah dan lain-lain baru jalur birokrasi dibuka dengan pengerahan 
aparat yang ada di daerah pelaksananya pihak kecamatan hanya sebatas membuat kebijakan seperti pembuatan Surat Keputusan dan Surat Perintah dan secara teknis ada pihak puskesmas

Disiplin

Kesadaran dan kesediaan anggota dalam menjalankan tugas dapat mendukung koordinasi yang baik antara instansi terkait. Kesadaraan akan tugas yang diberikan kepada Puskesma Pagaden dan Kantor Kecamatan Pagaden serta kesediaan untuk menjalankan tugas hal yang sangat dituntut untuk pencapaian tujuan. Tanpa adanya kesadaran dan kesediaan setiap anggota pelaksanaan program kesehatan lingkungan

\section{DAFTAR PUSTAKA}

Anwar Asrul.2003, Pengantar Ilmu Kesehatan Lingkungan, Jakarta: Mutiara

Daldjoeni, N dan A. Suyitno. 2002. Pedesaan, Lingkungan dan Pembangunan. Bandung: PT. Alumni.

Dessler, Gary, 2007. Manajemen Sumber Daya Manusia. Jakarta: Indeks

George R. Terry, 2010, Prinsip-prinsip Manajemen, Jakarta : PT. Bumi Aksara

Handayaningrat, Soewarno, 2006. Administrasi Pemerintah Dalam Pembangunan, Jakarta: Gunung Agung.

Handoko, T. H. 2005, Manajemen Personalia dan Sumber Daya Manusia. Yogjakarta: BPFE,

Hasibuan Malayu SP, 2006, Manajeman : Dasar, Pengertian dan Masalah, Jakarta : Bumi Aksara

Kaloh Johannis, 2006, Konsep Koordinasi Dalam Proses Administrasi, Jakarta : Istitut Ilmu Pemerintahan

Lexy J. Meloeng, 2005, Metode Penelitian Kualitatif, Bandung : PT Remaja Rosdakarya.
Martaperdana, Soma. 2005, Ilmu Kesehatan Masyarakat. Bandung: APDN

Moekijat, 2004, Koordinasi (Suatu Tindakan Teoritis), Bandung: Mandar Maju

Mutawali.2004, Partisipasi Masyarakat Dalam Pembangunan Desa. Bandung: Direktorat Bangdes

Nazir, M. 2009. Metode Penelitian. Jakarta : Ghalia Indonesia.

Rivai Veithzal, 2005, Manajemen Sumber Daya Manusia untuk Perusahaan, Raja Grafindo Persada: Jakarta.

Riyadi. Sugeng. 2006. Keperawatan Kesehatan Masyarakat . Jakarta: Salemba Medika

Siagian, Sondang, 2006. Manajemen Sumber Daya Manusia. Jakarta: Bumi Aksara.

Sudarsono, 2003, Beberapa Pendekatan Dalam Penelitian Kualitatif, Yogyakarta : Gadjah Mada University Press.

Sugiyono, 2009, Memahami Penelitian Kualitatif, Bandung : Alfabeta.

Suyanto, Bagong. 2005. Metode Penelitian Sosial: Berbabai Alternatif Pendekatan. Jakarta : Prenada Media

Wijayanti, Irine Diana Sari, 2008, Manajemen, Yogyakarta: Mitra Cendikia Press

Dokumen-Dokumen

Undang-Undang Republik Indonesia Nomor 36 Tahun 2009 Tentang Kesehatan

Undang-Undang Republik Indonesia Nomor 9 Tahun 1960 Tentang Pokok-Pokok Kesehatan

Undang-Undang Republik Indonesia Nomor 23 Tahun 1992 Tentang Kesehatan 